\title{
On the Way to Teaching as Letting Learn
}

\author{
Cynthia Taylor
}

Nova Scotia College of Art and Design

Heidegger (1968), according to translator Gray, was above all else a teacher. He regarded teaching as an exalted activity, a craft that can only take place when the teacher is more teachable than the students.

Teaching is even more difficult than learning because what teaching calls for is this: to let learn. The real teacher, in fact, lets nothing else be learned than-learning... The teacher is ahead of his apprentices in this alone, that he has still more to learn than they-he has to learn to let them learn. (Heidegger, p. 15)

This teaching as letting learn may be the most unsettling concept to grasp in pedagogy, but perhaps it is the most important. The attention and emphasis is on the student, who gropes his or her way toward personal understanding, who discovers, with surprise and delight, what it is like to own knowledge. What is the nature of teaching that allows learning to occur? And with what collusion and compliance on the part of the teacher does it proceed? How might conditions be established conducive to letting learn?

These questions become pointed for me when I am faced with the challenge to teach a course in art history to students who do not wish to learn. They are patently uninterested in either art or its history. They have no reason to study but for the demand that they take one art course in order to fulfill their bachelor degree requirements. I am faced with a choice. As the teacher, I can adopt a traditional role to organize the content of the course, to deliver the factual information, and to test for retention. That would be easy and would satisfy the most stringent scrutiny. But I am, at the same time, immersed in my own search. Reading Heidegger (1971), I am struck by his unequivocal statement: "To learn means to become knowing." And this dynamic reference to learning as a fluid process is restated: "To put oneself on a journey, to experience, means to learn" (p. 143).

The demand is clear. I have to learn, and to learn how to let my students learn. I am forced to address questions of meaning, both epistemological and pedagogical: What is knowing? What really matters? How does one learn? Can one bring a creative willingness, newly understood as poiesis, to the act of teaching? Can teaching be art-full?

I listen to the students and I try to trace the patterns and textures of their lives, their fears, their dreams. I introduce various themes that, I hope,

Phenomenology + Pedagogy Volume 91991 
will lead them to questions of personal meaning, toward taking responsibility for their learning, risking self-understanding and commitment.

One theme is metaphoric: The Journey. Gauguin's painting poses questions for us: Who are we? Where have we come from? Where are we going? Another theme concerns the experience of being alone: Solitude, Alienation, and Fear. I am anxious that these young people begin to discover that learning, as a process, happens in a variety of ways, not the least of which results from a productive aloneness: self with self. I read them fragments to prompt their reflection:

A Western man, a truly and purely Western man, cannot tolerate the feeling that he is nude and alone in an afternoon that is eternal. But if he has the courage to affront his own solitude, he will hear, but with something other than his ear of flesh, a new unsuspected music ... a music that imposes its rule, no longer on corporeal existence, but on a more intimate order, a more subtle form of existence ... The real goal of the music: to provoke man to become conscious of himself. (Daumal, 1982, p. 23)

I silently show works of art in which others have proclaimed "awareness and affirmation of, and gratitude and delight in the connected aloneness of each of us" (Miles, 1982, p. 101). And I bring images of relationship, in which the self is accompanied: with another, with things, with works of art. Although I provide information and ask them to write accounts of their own experiences as they learn about artworks, it is always with the express wish that these acts allow them the opportunity of learning in new ways. I wish that the work of art offers them access to their own self-understanding: "The recognition that the work of art procures for us is always an expansion of that infinite process of making ourselves at home in the world, which is the human lot" (Gadamer, 1977, p. 151).

The role of the teacher, in this new way of understanding pedagogical purpose, is radically altered. No longer solely the imparter of information-although, as Heidegger (1968) insists, "the teacher must have a larger store of information, and have it always ready" (p. 15) --the teacher must also be prepared to remain silent. "To be able to keep silent, Dasein must have something to say-that is, have at its disposal an authentic and rich disclosedness of itself" (Heidegger, 1962, p. 208).

With the best will in the world, many beginning teachers wish to pass on to their pupils all the ideas that have excited them. They want to save their students time, frustration, mistaken steps. They are bursting with energy and ideas, overflowing with information, anxious to be as efficient as possible in the transmission of the material they have garnered and which they consider important and worthy.

It is difficult to suggest that it is sometimes appropriate to be reticent, to withhold information, to withdraw from conversation as an active participant, so that they can be active in a different way, in the interest of letting learn. To teach in this way is not to cancel oneself out, but rather 
to listen openly, attentively. One must be silent and yet supportive, leaving space for learning. It requires that the teacher learn how to listen and how to speak from silence.

Krishnamurti (1974) places much importance on both these aspects of the experience of learning: "You learn when there is attention and silence. Learning is when you have silence and give complete attention. In that state you begin to learn" (p. 77). "If you listened, really listened, the flowering would take place" (p. 189).

The silence is not void, but productive. It is a silence that "rings," to use Heidegger's word. Learning will more often occur where one can "hear what is spoken in silence.... All voices and sounds must be put away and a pure stillness must be there, a still silence" (Caputo, 1978, p. 117). To teach in this way means to create an atmosphere, to provide a space wherein students are listened to, listen to the other, or to the silence of what the ancients called Great Nature. "You feel the world's word as a tension, a hum, a single chorused note everywhere the same. This is it: the hum is the silence.... We are here to witness" (Dillard, 1983, p. 72).

While exploring my own understanding of this radically new concept of teaching, I teach art education students, most of whom are about to enter the professional world of the classroom. Although all are trained artists, the course focuses on pedagogical concerns: Approaches to Teaching Drawing.

My determination is to exemplify my growing understanding of teaching as letting learn. And in the process, I hope as well to go beyond the pedagogical imperative and to provide access for the students to explore ancient ways of knowing.

Craighead (Gadon, 1989), herself an artist, says "We are born remembering; we are born connected.... Every drawing is a quest for origin, a return to the course following hidden threads in the labyrinthine matrix" (p. 240). I wish for the students to embark on a personal and inward journey, and at the center to discover and celebrate the experience of aloneness. I wish for them to be silent, and from the knowing core begin to speak from that stillness, to speak in "a new language, one tempered by silence and originating from silence" (Caputo, 1978, p. 172).

I simply ask that the students keep a sketchbook in which every day they find time and space to make a drawing and write from the experience. And I discover that I am unprepared for the power of this new approach connected to the time-tested suggestion that students keep journals. For the books trace the patterns of their emerging sense of selfhood, and the impact of working in new ways with familiar materials. It is evident that self-understanding is being transformed by fresh ways of thinking and knowing. Somehow, the daily discipline becomes a labor of love. The task is to relate images and words to express, self-reflectively, aspects of personal learning and knowing. 
The journal is the earth in which the root of self expands, growing downward and upward simultaneously. The boundaries between self and journal, root and earth, are tenuous, for it is in their relation to each other that life takes place. (Myerhoff \& Metzger, 1980, p. 110)

Other activities result in powerful works. Recognizing that most often artists work alone, I ask that this time each student work with another to witness the creative process. They sit with their counterparts, in a space chosen by the artist, and watch and listen while a drawing is brought to completion. It is a rare privilege, for each is enfriended. In the silence, the work is completed, nourished by the attention and interest of the witnessing partner, who learns about the mysterious process of making by simply being there, connected across the necessary aloneness. In the pauses that occur naturally, the watcher may make a photograph or photocopy of the work in process so they can together track its history. Later, they share their particular understanding of the work, each from his or her own perspective, and surrounded by the work in the various stages of its being brought into form. The partners then exchange roles and repeat the process. This turns out to be a profoundly moving experience for all concerned. It requires a new attitude, one of listening to and for the other. "If there is an ethics of listening, then respect for silence must play a part in that ethics" (Ihde, 1976, p. 184). At another time students are asked to work together on the same work of art, each contributing to what is to be a synthesis of individual styles, ideas, ways of working and knowing. I emphasize that each of these ways may illumine a particular way of being in which the ultimate goal is realization of the self, learned and celebrated in life.

Couldn't everyone's life become a work of art? We have to create ourselves as a work of art ... like Nietzsche's observation that one should create one's life by giving style to it through long practice and daily work. (Foucault, in Dreyfus \& Rabinow, 1982, p. 236)

On my way to understanding teaching as letting learn, I discover that a teacher must insist on fine language, attentive and attuned to the silence. The attempt must be to "overcome the extreme rationalization of the technical language on the one hand, and the superficiality of ordinary language on the other" (Caputo, 1978, p. 172). This happens if students are led toward taking responsibility for their own learning, their own knowing. The language they employ will attest to the power of the journey, the experience of learning. The teacher must provide private space, psychic and physical space, in which the student can be alone, listening to inner silence. He or she can present sayings of others and objects (art works, stones, bones) that have a potential for awakening a contemplative attitude in the beholder. Most important of all, perhaps, is the teacher's own openness to learning and knowing, a continual and vital process of growth. One must let oneself learn. 


\section{References}

Caputo, J. (1978). The mystical element in Heidegger's thought. Athens, GA: Oberlin. Daumal, R. (1982). Rasa or knowledge of the self (L. Landes Levi, Trans.). New York: New Directions.

Dillard, A. (1983). Teaching a stone to talk. New York: Harper Colophon.

Dreyfus, H.L., \& Rabinow, P. (1982). Beyond structuralism and hermeneutics. Chicago, IL: University of Chicago Press.

Gadamer, H.G. (1977). Philosophical hermeneutics (D.E. Linge, Trans. \& Ed.). Berkeley, CA: University of California Press.

Gadon, E.W. (1989). The once and future goddess. New York: Harper and Row.

Heidegger, M. (1962). Being and time (J. Macquarrie \& E. Robinson, Trans.). London: SCM Press.

Heidegger, M. (1968). What is called thinking? (J.G. Gray, Trans.). New York: Harper and Row.

Heidegger, M. (1971). On the way to language (P.D. Hertz, Trans.). San Francisco: Harper and Row.

Ihde, D. (1976). Listening and voice: A phenomenology of sound. Athens, $\mathrm{OH}$ : Ohio University Press.

Krishnamurti. (1974). On education. New York: Harper and Row.

Miles, M.R. (1982). The courage to be alone. In M.E. Giles (Ed.), The feminist mystic (pp. 84-102). New York: Crossroad.

Myerhoff, B., \& Metzger, D. (1980). The journal as activity and genre. Semiotica, 30(1/2), 97-114. 